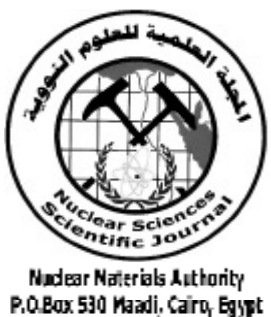

ISSN 2314-5609

Nuclear Sciences Scientific Journal

$5,133-145$

2016

http://www.ssnma.com

\title{
PETROCHEMICAL AND RADIOACTIVE CHARACTERISTICS OF EL- YATIMA MONZOGRANITE, CENTRAL EASTERN DESERT, EGYPT
}

\author{
TAREK F. MOHAMMADEN; ABDEL MOEZ A. SADEK; MOHAMED O. EL- \\ HUSSEINY and AHMED H. ABDEL MAABOOD \\ Nuclear Materials Authority. P. O. Box 530, El-Maadi, Cairo, Egypt
}

\begin{abstract}
The younger granite in El-Yatima area, Central Eastern Desert, cropped out as an isolated mass intruding the older granitic rocks with sharp contacts. It is of pink to reddish color, equigranular of hypidiomorphic texture being porphyritic in places. It is composed of plagioclase, quartz, perthite and biotite as the main constituent minerals.

Petrological and geochemical data assigned the studied granite as monzogranite that exhibits calcalkaline with weak peraluminous affinity, magmatic nature which is emplaced in within-plate tectonic environment as A-type granite. Its uranium content is of magmatic origin which is probably leached from its bearing metamectized zircon. El-Yatima monzogranite is characterized by low fractionated REE pattern [Av. $(\mathrm{La} / \mathrm{Lu}) n=1.86]$ with slight enrichment of LREE [Av. $(\mathrm{La} / \mathrm{Sm}) n=1.46]$ relative to approximate flat HREE [Av. $(\mathrm{Gd} / \mathrm{Lu}) \mathrm{n}=0.93$ ]. The modeled REE data supports the bulk continental crust (B.C.C.) as a parent source of El-Yatima monzogranite melt which had evolved through $70 \%$ partial melting of the parent source followed by $30 \%$ fractional crystallization.
\end{abstract}

\section{INTRODUCTION}

The Pan-African terrane in the Central Eastern Desert at Lat. $25^{\circ}$ comprising El-Yati$\mathrm{ma}$ area, consist of four major tectonic groups; [1] ophiolitic sequence being intruded by [2] a metamorphosed island arc assemblage of calc-alkaline metagabbro-diorite complexes, metavolcanics and their pyroclastic rocks and older granitoids of tonalite-granodiorite composition (El-Gaby et al., 1988). These are overlain by [3] molasse-type Hammamat sediments which are intimately associated with intermediate Dokhan Volcanics (El-Gaby et al., 1988) and intruded by [4] post-orogenic younger granites (Hussein et al., 1982).

The younger granitoids occupy a significant area. They reach up to $16 \%$ of the ex- posed basement rocks in the Eastern Desert (Stern, 1979). Therefore, they were the main subject in huge number of previous work, their classification was a main point of interest. They were classified as Gattarian granites (Hume, 1935), late-orogenic granites (ElShazly, 1964), peraluminous alkali-granites (Greenberg, 1981), G2 granites (Hussein et al., $1982)$ and G $\beta$ granites (El Gaby et al., 1988). They comprise monzogranites, syenogranites and alkali feldspar granites and they range in magmatic composition from calc-alkaline to alkaline. Based on their field relation, petrographical and geochemical features, Akaad \& Noweir (1980) and Greenberg (1981) grouped them in three phases; phase I, II and III where phase I is the least differentiated and phase III is the highly differentiated one. Some of the 
younger granitic plutons show A-type geochemical signature such as low $\mathrm{CaO}$ and high $\mathrm{SiO}_{2}$, total alkalis, $\mathrm{Nb}$ and $\mathrm{Y}$ (Mohamed, 1993 and Mohamed et al., 1994). Although the Atype granites are commonly of within plate tectonic origin, but they can also be formed in other tectonic settings, including the active subduction zones (Whalen et al., 1987; Lumbers et al., 1991 and Eby, 1992). The origin of the A-type granites in the Nubian Shield was believed to be related to the extensional tectonics (Abdel-Rahman \& Martin, 1990)

Petrogenesis and origin of the granitic rocks are successfully obtained, to high extent, using rare earth elements modeling calculations where several origins were estimated such as derivation from partial melting of the mantle, the subducted oceanic crust or lower continental crust. The melt may be modified by fractionation, mixing with other melts, or reaction with crustal rocks of different composition during its ascending over wide range of $\mathrm{P}, \mathrm{T}$ and $\mathrm{P}_{\mathrm{H} 2 \mathrm{O}}$ conditions.

Although several studies were carried out on El-Yatima granitic pluton (Sabet et al. 1973, Kamel \& Abdel Hadi, 1982, Salem, 1983, Moghazy et al., 1999 and Sadek, 2006) but no previous data of rare earth elements (REEs) are available on this granite.
This paper presents new REE data that will be employed to get some aspects around the origin of El-Yatima monzogranite in addition, revealing its petrographical and geochemical features as well as the distribution of its contents of radioactive elements.

\section{GEOLOGIC SETTING AND PETROGRAPHY}

The investigated area is located at the southern part of the Central Eastern Desert (CED) lying between Lat. $25^{\circ} 05^{\prime}-25^{\circ} 10^{\prime} \mathrm{N}$ and Long. $34^{\circ} 10^{\prime}-34^{\circ} 13^{\prime}$ E. El Yatima granite occurs as isolated irregular small-dissected granitic mass (Fig. 1) covering an area of about $9 \mathrm{~km}^{2}$ forming moderate to low topographic features, with high relief reaching 848 m. a.s.l. It intrudes the low-lying older granites with sharp contacts. It encloses rounded granodioritic xenoliths up to $25 \mathrm{~cm}$ across (Moghazy et al., 1999). This pluton is pink to reddish, equigranular, massive, blocky and bouldary granite. It is characterized by exfoliation, hematitization and silicification as alteration products. Generally, it is dissected by fractures and joints trending in different directions. It is also dissected by a set of NW-SE and NNW-SSE faults along which the granite is sheared and foliated. The stud-

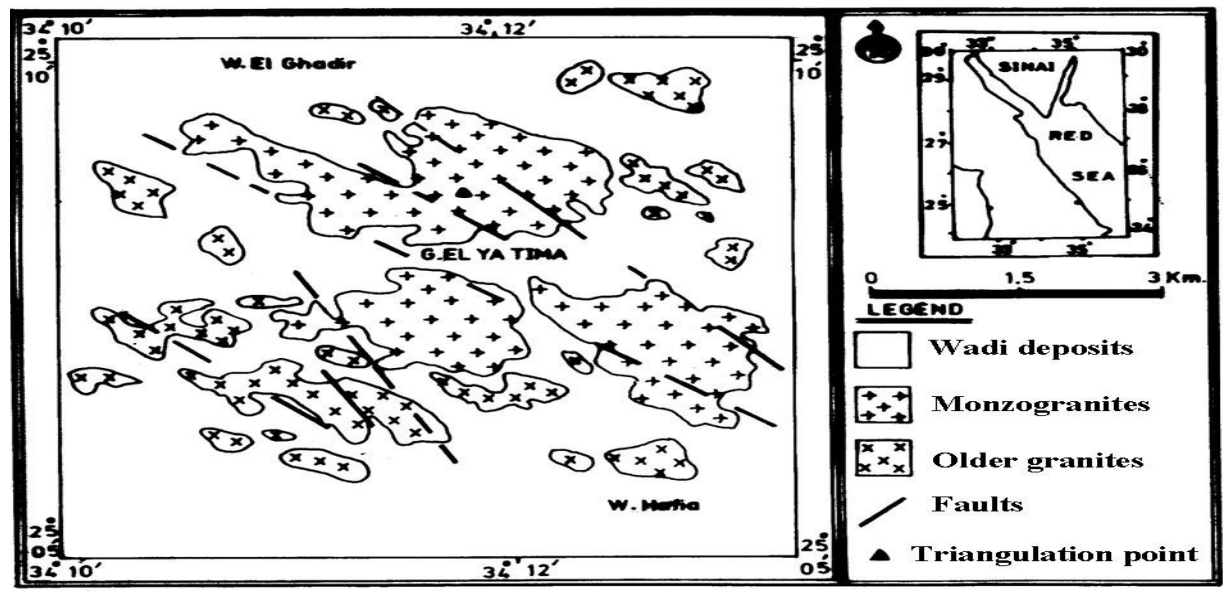

Fig. 1: Geologic map of El-Yatima area (Sadek, 2006) 
ied granite shows the strong effect of shearing along the fault planes (Sadek, 2006).

Petrographically, the modal mineralogical compositions of 8 selected samples from the studied granite are given in Table (1). Using the QAP ternary diagram of Streckeisen (1976 b), the studied samples are assigned as monzogranite (Fig. 2).

El-Yatima monzogranite is mainly medium- to coarse-grained, commonly of equigranular hypidiomorphic texture. It is composed of plagioclase, quartz, K-feldspars

Table 1: Modal composition of the studied monzogranite

\begin{tabular}{lrrrrrr}
\hline S. No. & Quartz & $\begin{array}{r}\text { K- } \\
\text { feldspare }\end{array}$ & Plagioclase & Biotite & Ac.+0p. & Total \\
\hline 1 & 35 & 30 & 33 & 1.5 & 1 & 100 \\
2 & 36 & 31 & 30 & 1 & 0.5 & 98.5 \\
3 & 32 & 33 & 33 & 1.5 & 0.5 & 100 \\
4 & 32 & 31 & 35 & 1 & 1 & 100 \\
5 & 35 & 29 & 34 & 0.5 & 0.5 & 99 \\
6 & 34 & 32 & 32 & 1 & 0.5 & 99.5 \\
7 & 31 & 33 & 35 & 0.5 & 0.5 & 100 \\
8 & 33 & 27 & 37 & 1 & 1 & 99 \\
Av. & 34 & 31 & 34 & 1 & 0.5 & 100.5 \\
\hline
\end{tabular}

- Ac. + Op. $=$ Accessories and opaques

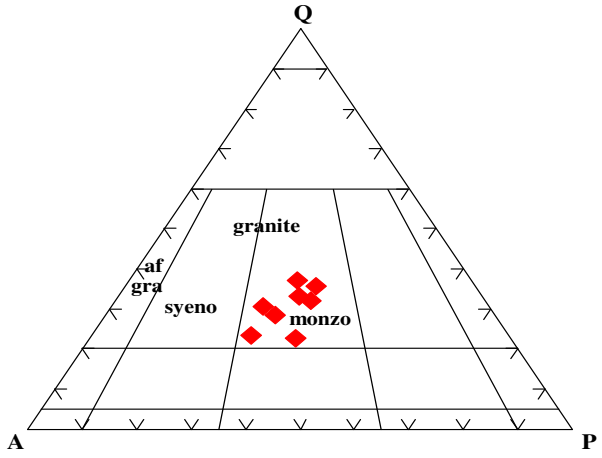

Fig.2: The modal composition of El-Yatima granite (Streckeisen, 1976 b)

and subordinate amount of biotite. Zircon, allanite and opaques are the main accessory minerals.

Plagioclase (oligoclase, $\mathrm{An}_{25}$ ) occurs as subhedral to euhedral tabular crystals of coarse- to medium-grain size. These crystals have cloudy and dusty appearance exhibiting albitic lamellar twinning. Sometimes, zoned crystals show selective alteration in the core being partially saussuritized and deformed lamellae and corroded by microcline (Fig. 3).

K-feldspars mainly orthoclase and microcline perthites are found as anhedral to subhedral prismatic crystals medium- to coarsegrained of string and patchy types. Orthoclase perthite occurs as euhedral prismatic crystals with simple twinning in some plates, while the microcline perthite exhibits cross-hatching and is corroded by quartz (Fig. 4).

Quartz occurs as primary and secondary generations. The primary quartz occurs as elongated fuzzy grains showing strong undu-

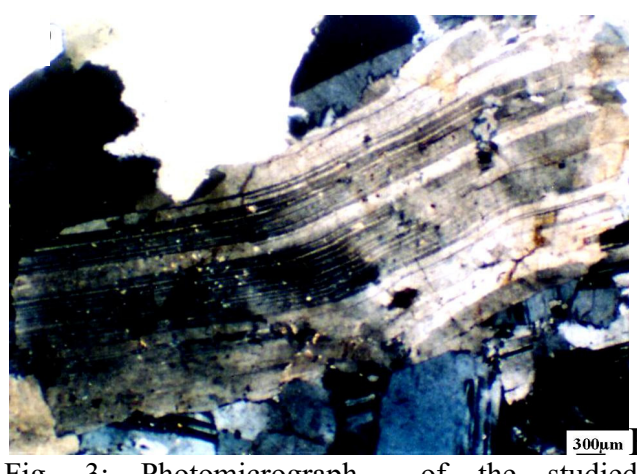

Fig. 3: Photomicrograph of the studied monzogranite showing deformed and twisted lamellae of plagioclase

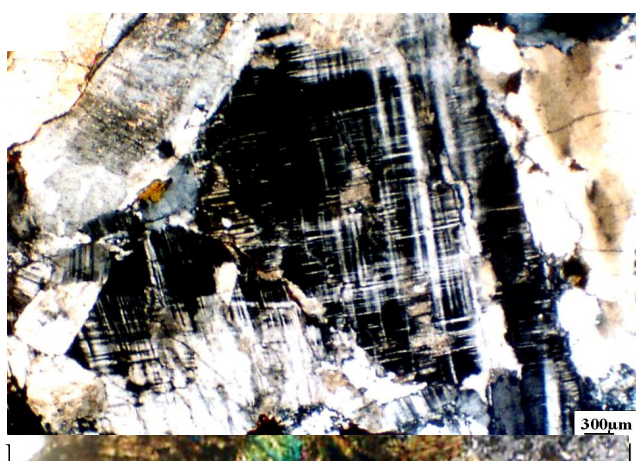

4: Photomicrograph of the studied monzogranite showing microcline shows crosshatching twinning 
lose extinction (Fig. 5) indicating the effect of stress, while the secondary generation occurs as very fine rounded crystals interstitial between feldspar crystals.

Biotite occurs as small flakes of brown color (Fig. 6) showing pleochrism, chloritization, and muscovitization and somtimes mottled with iron oxides associated with some accessory minerals.

Small aggregated euhedral to subhedral prismatic crystals of zircon which are usually embedded in quartz and feldspars surrounded by iron oxides (Fig. 7), occasionally some zircon crystals suffer partial metamictization. Allanite occurs as subhedral deep reddish brown crystals associated with biotite (Fig. 8). Opaques occur as patches and/or skeletal crystals of iron oxides in association with biotite.

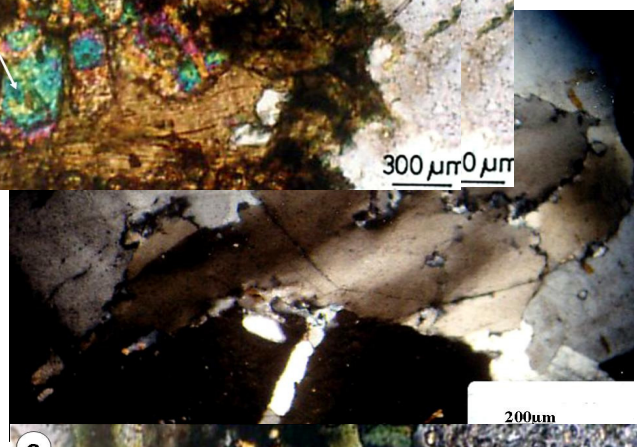

Fig. 5: Photomicrograph of the studied monzogranite showing large grains of fuzzy quartz showing undulose extinction

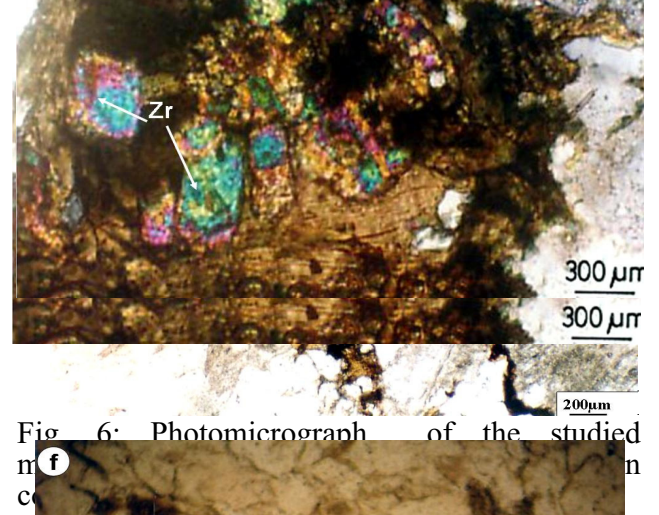

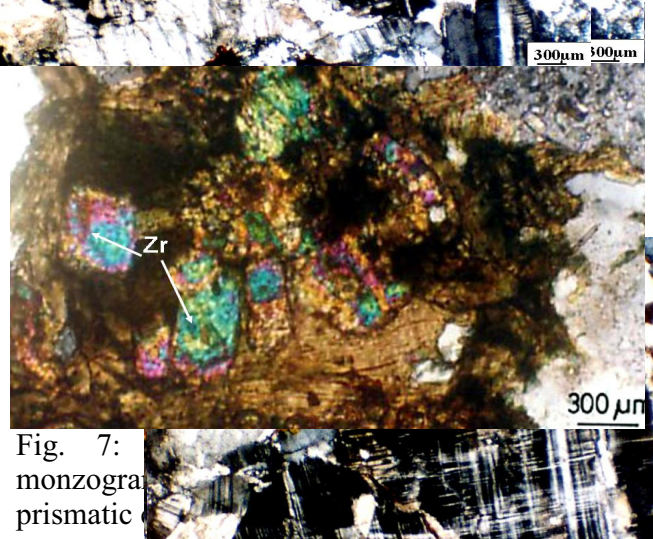

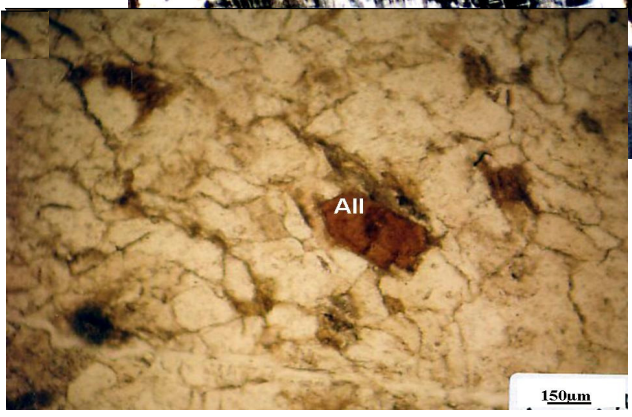

Fig. 8: Photomicrograph of the studied monzogranite showing euhedral crystal of deep brown allanite

\section{GEOCHEMISTRY}

Ten carefully selected representative samples of El-Yatima monzogranite arechemically analysed to determine their chemical composition. The major oxides aredetermined using the wet chemistry techniques (Shapiro \& Brannock, 1962) at the Nuclear Materials Authority's Laboratories. Both trace and rare earth elements are measured by the ICP-MS that installed in the ACME Labs. Vancouver, Canada. Analytical precision was monitored to be better than $\pm 2 \%$ for major oxides and $\pm 3 \%$ to $\pm 10 \%$ for trace and rare earth elements. Results of the major oxide and their calculated CIPW norm are given in Table (2), while results of the chemical analysis of trace and rare earth elements are given in Tables (3 \& 4) respectively. 
PETROCHEMICAL AND RADIOACTIVE CHARACTERISTICS OF EL-

Table 2: Major oxides data and CIPW norm of El-Yatima granites

\begin{tabular}{|c|c|c|c|c|c|c|c|c|c|c|c|}
\hline S. No. & 1 & 2 & 3 & 4 & 5 & 6 & 7 & 8 & 9 & 10 & Average \\
\hline $\mathrm{SiO}_{2}$ & 73.5 & 73.1 & 72.8 & 72.6 & 73.2 & 73 & 72.4 & 73.1 & 73.6 & 72.8 & 73 \\
\hline $\mathrm{TiO}_{2}$ & 0.07 & 0.09 & 0.1 & 0.08 & 0.09 & 0.1 & 0.07 & 0.02 & 0.1 & 0.07 & 0.08 \\
\hline $\mathbf{A l}_{2} \mathbf{O}_{3}$ & 13.8 & 14.1 & 14.1 & 14 & 13.2 & 13.7 & 13.6 & 13.2 & 14 & 13.5 & 13.72 \\
\hline $\mathrm{Fe}_{2} \mathrm{O}_{3}$ & 1.2 & 0.9 & 1.1 & 0.8 & 1.92 & 1.72 & 1.68 & 0.96 & 1.2 & 1.3 & 1.3 \\
\hline FeO & 0.74 & 0.62 & 0.65 & 0.55 & 0.85 & 0.73 & 0.89 & 0.63 & 0.75 & 0.72 & 0.71 \\
\hline MnO & 0.04 & 0.03 & 0.05 & 0.04 & 0.04 & 0.05 & 0.06 & 0.06 & 0.05 & 0.04 & 0.05 \\
\hline MgO & 0.6 & 0.8 & 0.7 & 0.9 & 1.1 & 1.4 & 1.01 & 1.12 & 0.8 & 0.6 & 0.9 \\
\hline CaO & 1.12 & 1.3 & 1.4 & 1.1 & 1.3 & 1.7 & 1.2 & 1.4 & 1.1 & 1.2 & 1.3 \\
\hline $\mathrm{Na}_{2} \mathrm{O}$ & 3.82 & 4.1 & 3.9 & 4.2 & 3.96 & 3.82 & 4 & 3.87 & 3.9 & 4.1 & 3.97 \\
\hline $\mathbf{K}_{2} \mathbf{O}$ & 3.51 & 3.7 & 3.6 & 3.7 & 3.42 & 3.57 & 3.43 & 3.51 & 3.6 & 3.7 & 3.57 \\
\hline $\mathbf{P}_{2} \mathbf{O}_{5}$ & 0.08 & 0.01 & 0.07 & 0.06 & 0.07 & 0.08 & 0.03 & 0.04 & 0.05 & 0.07 & 0.06 \\
\hline LOI & 1.2 & 1 & 1.5 & 1.3 & 1.4 & 0.8 & 1.4 & 1.6 & 0.9 & 1.6 & 1.3 \\
\hline Total & 99.68 & 99.75 & 99.97. & 99.33 & 100.85 & 100.67 & 99.77 & 99.51 & 100.05 & 99.7. & \\
\hline \multicolumn{12}{|c|}{ CIPW norm } \\
\hline $\mathbf{Q z}$ & 35.63 & 31.46 & 33.29 & 31.44 & 33.48 & 31.88 & 32.52 & 33.52 & 34.29 & 32.38 & 33 \\
\hline Or & 21.18 & 22.30 & 21.81 & 22.57 & 25.58 & 21.35 & 20.60 & 21.343 & 21.64 & 22.47 & 22 \\
\hline $\mathbf{A b}$ & 33.04 & 35.31 & 33.76 & 36.6 & 33.96 & 32.57 & 34.33 & 33.62 & 33.50 & 35.58 & 34 \\
\hline An & 5.21 & 6.52 & 6.70 & 5.27 & 6.15 & 8.04 & 5.87 & 6.90 & 5.25 & 5.70 & 6.2 \\
\hline
\end{tabular}

Table 3: Trace elements (ppm) data of El-Yatima monzogranite

\begin{tabular}{|c|c|c|c|c|c|c|c|c|c|c|c|}
\hline S.No. & 1 & 2 & 3 & 4 & 5 & 6 & 7 & 8 & 9 & 10 & Average \\
\hline $\mathbf{B a}$ & 28.3 & 130.8 & 311.3 & 237.4 & 57.6 & 195.1 & 51.1 & 47.1 & 18.5 & 106.8 & 118 \\
\hline $\mathrm{Sr}$ & 14.7 & 32.5 & 85.3 & 55.9 & 25.2 & 54.2 & 15.8 & 12.8 & 8.9 & 37.5 & 34 \\
\hline $\mathbf{R b}$ & 160.1 & 170.5 & 159.7 & 171.3 & 268.3 & 180 & 266 & 222.4 & 241.9 & 185.4 & 203 \\
\hline Nb & 27 & 19.2 & 16.4 & 24.7 & 43.3 & 19.6 & 55.1 & 46.6 & 64.3 & 25.8 & 34 \\
\hline $\mathbf{Y}$ & 61.3 & 81.1 & 48.4 & 66.8 & 117.2 & 79.2 & 140.8 & 79.4 & 130.7 & 103.5 & 91 \\
\hline $\mathbf{Z r}$ & 115.8 & 177.4 & 205.5 & 189 & 97.4 & 139.3 & 136.3 & 107.9 & 115.6 & 126.8 & 141 \\
\hline Hf & 5.3 & 6.8 & 6.9 & 6.9 & 5.7 & 5.6 & 6.7 & 5.1 & 7.7 & 5.4 & 6 \\
\hline $\mathbf{G a}$ & 24.9 & 24 & 21.7 & 23.3 & 25.6 & 23.5 & 32.3 & 28 & 30.9 & 24.3 & 26 \\
\hline $\mathbf{T a}$ & 2.5 & 1.6 & 1.6 & 1.9 & 4.5 & 2.4 & 3.6 & 3.7 & 6.6 & 3.1 & 3 \\
\hline $\mathbf{Z n}$ & 61 & 67 & 53 & 74 & 33 & 61 & 70 & 10 & 69 & 50 & 55 \\
\hline Th & 12 & 14 & 13.5 & 14.5 & 27.6 & 13.9 & 16.7 & 12.8 & 48.8 & 17.7 & 19 \\
\hline $\mathbf{U}$ & 5 & 4.4 & 3.8 & 3.2 & 11.6 & 4.6 & 7.1 & 5.8 & 13.2 & 5.8 & 7 \\
\hline $\mathbf{T h} / \mathbf{U}$ & 2.4 & 3.18 & 3.5 & 4.53 & 2.37 & 3.02 & 2.35 & 2.2 & 3.69 & 3.05 & 3.3 \\
\hline
\end{tabular}

Table 4: REE data of El-Yatima monzogranite

\begin{tabular}{|c|c|c|c|c|c|c|c|c|c|c|c|}
\hline S.No. & 1 & 2 & 3 & 4 & 5 & 6 & 7 & 8 & 9 & $\mathbf{1 0}$ & Av. \\
\hline $\mathbf{L a}$ & 15.3 & 31.6 & 26 & 41.8 & 7.9 & 23.5 & 10.5 & 13.2 & 5.9 & 19.2 & 19.49 \\
\hline $\mathrm{Ce}$ & 45.2 & 86.4 & 64.3 & 108.3 & 21.9 & 61 & 31.6 & 35.3 & 19.5 & 50 & 52.35 \\
\hline Pr & 6.34 & 11.08 & 7.85 & 13.51 & 3.17 & 7.88 & 4.63 & 5.63 & 3.16 & 6.77 & 7.00 \\
\hline Nd & 27.9 & 43.6 & 30 & 54.1 & 14.2 & 31.5 & 20.9 & 24.5 & 16.1 & 26.3 & 28.91 \\
\hline Sm & 7.6 & 10.4 & 6.3 & 11.5 & 5.8 & 8.7 & 7.8 & 7.7 & 7.3 & 8.1 & 8.12 \\
\hline Eu & 0.42 & 0.61 & 0.76 & 0.87 & 0.27 & 0.55 & 0.27 & 0.2 & 0.09 & 0.4 & 0.44 \\
\hline Gd & 7.89 & 9.89 & 5.81 & 10.34 & 8.6 & 9.54 & 10.87 & 9.76 & 10.83 & 9.69 & 9.32 \\
\hline $\mathbf{T b}$ & 1.66 & 2.38 & 1.14 & 2.11 & 2.38 & 2.13 & 2.62 & 2.09 & 2.92 & 2.32 & 2.18 \\
\hline Dy & 8.93 & 12.6 & 6.44 & 11.39 & 15.34 & 12.25 & 15.69 & 11.99 & 19.04 & 14.33 & 12.80 \\
\hline Ho & 1.93 & 2.62 & 1.37 & 2.13 & 3.47 & 2.5 & 3.61 & 2.43 & 4.36 & 3.12 & 2.75 \\
\hline Er & 6.07 & 7.72 & 4.68 & 6.36 & 11.77 & 7.72 & 12.05 & 7.66 & 14.33 & 10.03 & 8.84 \\
\hline Tm & 0.92 & 1.16 & 0.77 & 0.98 & 1.91 & 1.15 & 1.92 & 1.21 & 2.33 & 1.61 & 1.40 \\
\hline $\mathbf{Y b}$ & 6.22 & 7.37 & 5.29 & 6.15 & 12.99 & 7.2 & 12.62 & 7.85 & 12.25 & 10.73 & 8.87 \\
\hline Lu & 0.96 & 1.11 & 0.85 & 0.93 & 1.95 & 1.06 & 1.74 & 1.13 & 2.08 & 1.58 & 1.34 \\
\hline$\sum$ LREE & 102.76 & 183.69 & 135.21 & 230.08 & 53.24 & 133.13 & 75.7 & 66.33 & 52.05 & 110.77 & 116.32 \\
\hline$\sum$ HREE & 34.58 & 44.85 & 26.35 & 40.39 & 58.41 & 43.55 & 61.12 & 44.12 & 68.14 & 53.41 & 47.49 \\
\hline
\end{tabular}


On the Or-Ab-An ternary diagram of Streckeisen (1976 a), the studied granitic samples fall in the monzogranite field (Fig. 9), this is in accordance with the petrography (Fig. 2). On the Middlemost (1997) diagram, all the plotted samples exhibit a nature of non-alkaline magma (Fig. 10). Calculation of Shand index (1951) of alumina saturation (Fig. 11) reveals that El-Yatima granite has peraluminous affinity although all the samples plot close to the border of the metaluminous field that may indicate their weak peraluminous tendency.

On the $\mathrm{Na}_{2} \mathrm{O} \%-\mathrm{K}_{2} \mathrm{O} \%$ variation diagram (Fig. 12) where three granitic types are discriminated; I- \& S-types (After White and

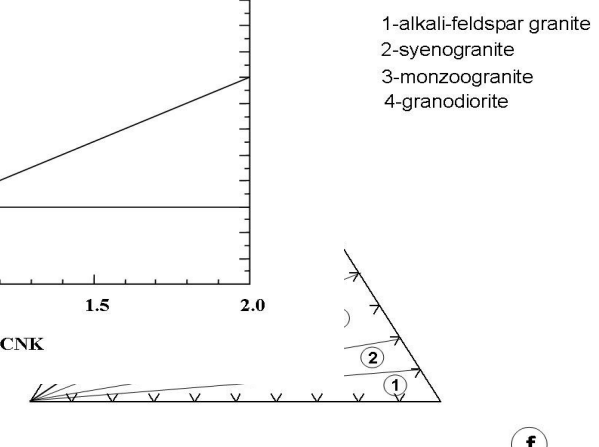

Fig. 9: Ab-An-Or ternary diagram (According to Streckeisen, 1976a)

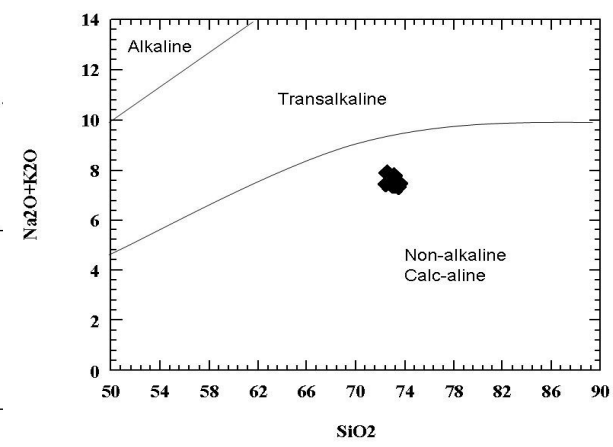

Fig. 10: $\mathrm{SiO}_{2}-\left(\mathrm{Na}_{2} \mathrm{O}+\mathrm{K}_{2} \mathrm{O}\right)$ diagram (According to Middlemost, 1997)

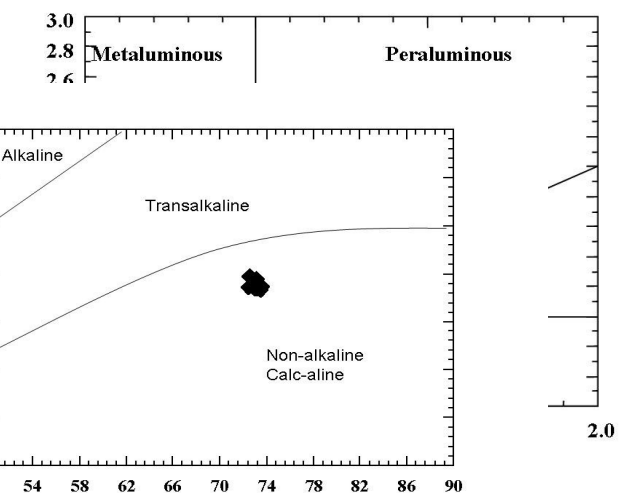

Fig. 11: ANK-ACNK digram (According to Shand,1951)

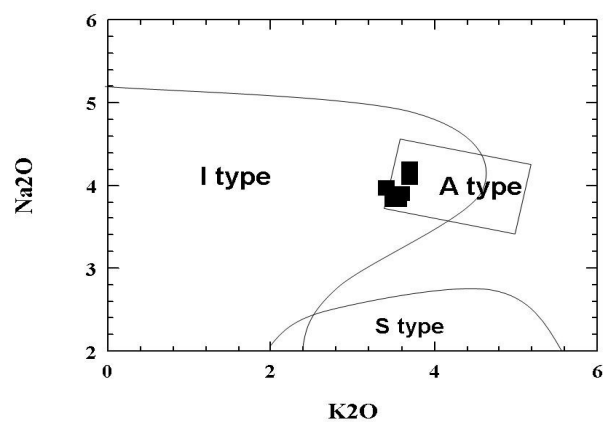

Fig. 12: $\mathrm{Na}_{2} \mathrm{O}-\mathrm{K}_{2} \mathrm{O}$ variation digram (fields $\mathrm{I} \& \mathrm{~S}$ according to White and Chappell ,1984 and field A, according to Liew et al. ,1989)

Chappell, 1984) and A-type (after Liew et al., 1989), the examined samples are plotted in the A-type field. More discrimination between I- and A-type is obtained on $\mathrm{SiO}_{2}-\mathrm{Y}$ diagram (Gunther et al., 1989) where most of the plotted samples are linked to the A-type granite (Fig. 13). Maniar and Piccoli (1989) used the binary relation of $\mathrm{Al}_{2} \mathrm{O}_{3}$ versus $\mathrm{SiO}_{2}$ (Fig. 14) to detect the tectonic settings of the granitic rocks. This diagram shows that the plotted samples are related to the post- orogenic granite field (POG).

Discrimination between the tectonic settings of different granitoid rocks of various affinities has been proposed by Pearce et al. 


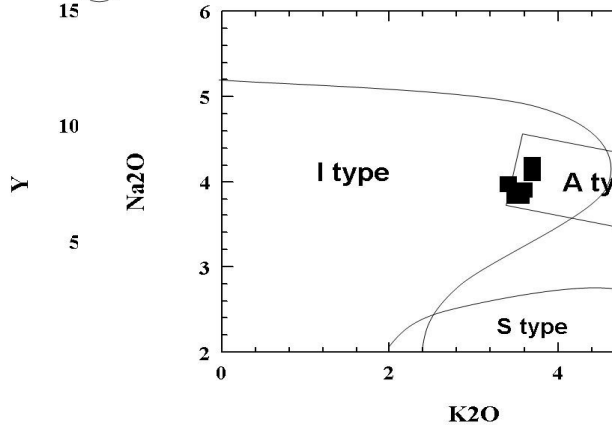

Fig. 13: $\mathrm{Y}-\mathrm{SiO}_{2}$ diagram (According to Gunther et.al. ,1989)

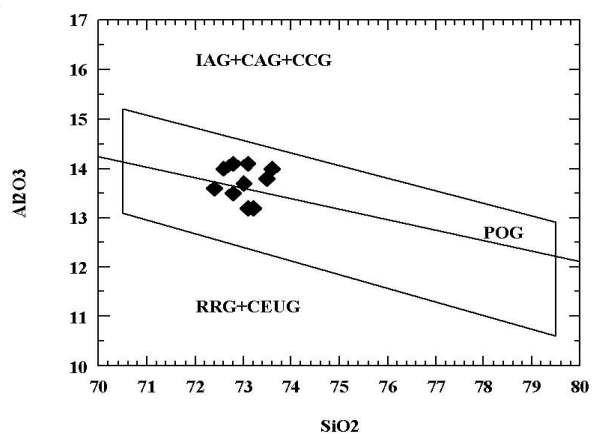

Fig. 14: $\mathrm{Al}_{2} \mathrm{O}_{3}-\mathrm{SiO}_{2}$ diagram (According to Maniar and Piccoli ,1989)

(1984). On this widely used diagram (Fig. $15)$, the data points of El-Yatima monzogranite plot in the within-plate granite field and are of comparable composition with the Atype granites of Whalen et al. (1987).

\section{URANIUM AND THORIUM DISTRIBUTION}

The averages of $U$ and Th contents in ElYatima monzogranite are $7 \mathrm{ppm}$ and $19 \mathrm{ppm}$ respectively. These values are within the reported ranges (1-6 ppm U and 1-23 ppm Th) for the granitic rocks (Adams et al., 1959). Also, the detected $U$ and $T h$ contents are more or less similar to the values reported for the post-orogenic granites of Saudi Arabia (5.6 ppm $U$ and $16.9 \mathrm{ppm}$ Th) after Stuckless et al. (1984). However, the uranium content is still under the estimated values of uranium in the

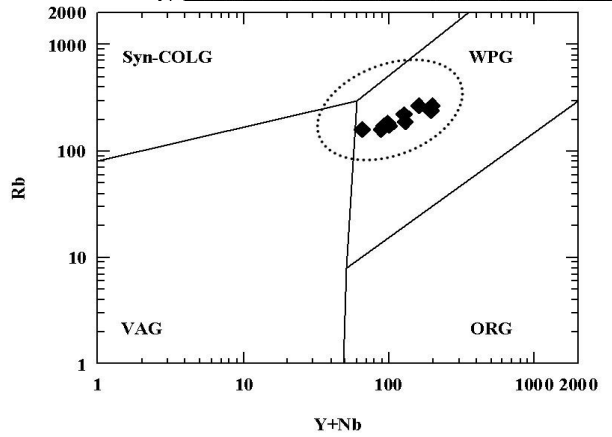

Fig. 15: $\mathrm{Rb}-\mathrm{Y}+\mathrm{Nb}$ diagrams (According to Pearce et al. ,1984; the dashed line represents the postcollision granite field according to Pearce ,1996)

uraniferous granites which is 8 ppm (Darnley, 1982) and more than $18 \mathrm{ppm}$ as mentioned by Assaf et al. (1997).

The low uranium content and absence of secondary uranium minerals strongly assume the magmatic origin of the uranium in El-Yatima monzogranite, such assumption could be verified through the binary relations between $\mathrm{Zr}-\mathrm{U}$ and Th-U based on the established magmatic origin of both $\mathrm{Zr}$ and $\mathrm{Th}$. Such relations in the studied granites revealed moderate positive relation between $\mathrm{Th}$ and $\mathrm{U}$ and non-definite relation between $\mathrm{Zr}$ and $\mathrm{U}$ (Figs. 16\&17). This disturbed relation could be interpreted by the leaching of uranium from the partial metamict zircon recorded in the petrographic study.

This interpretation is supported by the calculated $\mathrm{Th} / \mathrm{U}$ ratio in the investigated samples which is 3.3 in average, normally thorium is three times as abundant as uranium in rocks (Rogers and Adams, 1969). When this ratio becomes $>3.0$, it indicates a depletion of uranium during post magmatic processes (Dardier et al., 2002).

\section{RARE EARTH ELEMENTS (REE $\left.{ }_{s}\right)$}

The REE relative abundance are among the best parameters to detect the tectonic environments and the petrogenetic aspects of the granitoid rocks due to their stability and the negligible or no effect imparted by low 
TAREK F. MOHAMMADEN et al.

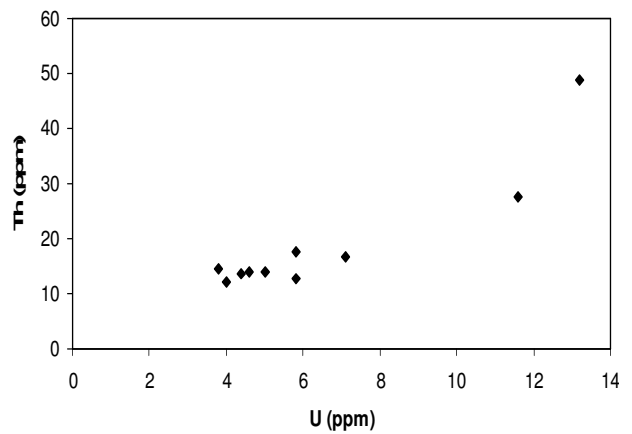

Fig. 16: Th-U binary relationship in El-Yatima monzogranite

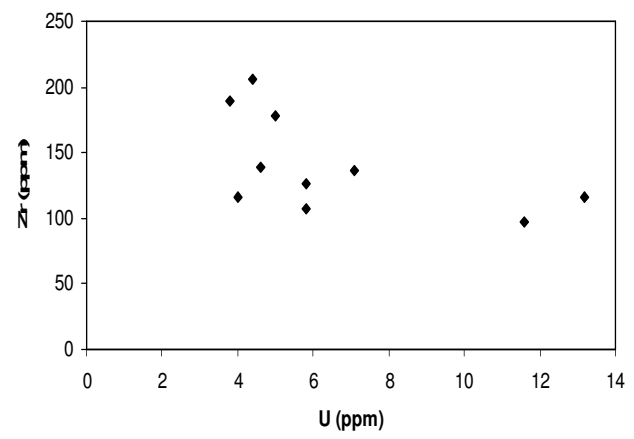

Fig. 17: $\mathrm{Zr}-\mathrm{U}$ binary relationship in El-Yatima monzogranite

grade metamorphism, weathering and/or the hydrothermal alterations.

To conduct considerable meanings from the REE values, they should be normalized against a chondrite values, the obtained REE data (Table 4) were normalized to the chondrite values after Taylor and McLennan (1985). Some normalized REE ratios were calculated as shown in Table (5) and the REE normalized pattern was constructed (Fig. 18). As revealed from both the REE normalized ratios and pattern, El-Yattima monzogranite is characterized by general low fractionated REE pattern $[(\mathrm{La} / \mathrm{Lu}) n$ ranges from 0.29 to 4.66 with an average ratio $=1.86]$ and slight enriched LREE $[(\mathrm{La} / \mathrm{Sm}) \mathrm{n}$ ranges from 0.51 to 2.95 with an average ratio $=1.46$ ] relative to the approximate flat HREE pattern $[(\mathrm{Gd} /$ $\mathrm{Lu}) \mathrm{n}$ ranges from 0.55 to 1.38 with an average ratio $=0.93]$.
Table 5: Some calculated normalized REE ratios of El-Yatima monzogranite

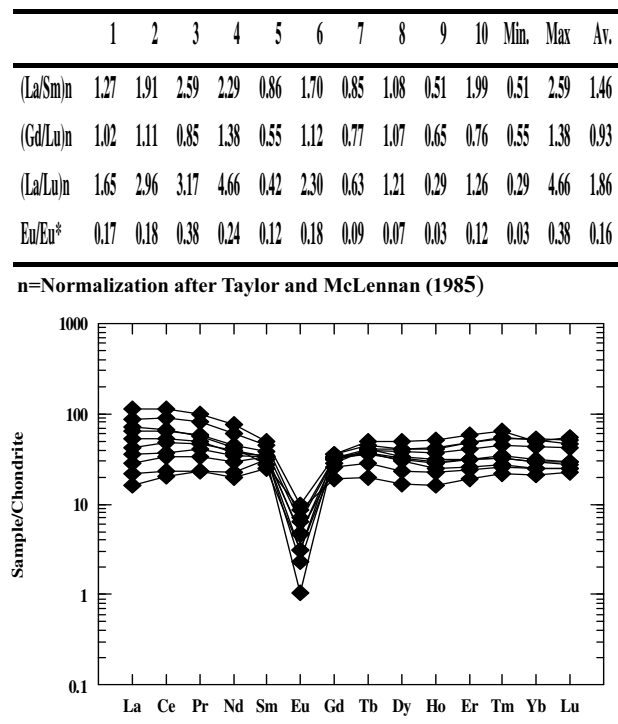

Fig. 18: Chondrite-normalized REE pattern of ElYatima monzogranite. Normalization after Taylor and McLennan (1985)

Some samples are of relative high HREE concentrations which are matching with their zircon contents as revealed by the petrographic studies, where zircon is known to concentrate HREE in granitic rocks (Arth, 1976 and Hanson, 1978). On the other hand, other samples show relatively high LREE contents which are confirmed by the presence of allanite in the petrographic study, where the REE bearing minerals such as sphene, allanite and apatite represent potential contribution to the LREE concentration (Miller and Mittlefehldt, 1982).

Also, the investigated monzogranite shows a distinctive - ve Eu-anomaly which is strongly supported by $\mathrm{Eu} / \mathrm{Eu}^{*}$ ratios which range from 0.03 to 0.38 with an average ratio equals 0.16 . Such - ve Eu-anomaly could be ascribed to the removal of plagioclases from the felsic melt by fractionation and/or that the parent felsic melt was derived from partial melting of source rocks in which most the feldspars were kept in the source. Another rea- 
sonable interpretation for the -ve Eu-anomaly was mentioned by Grenne and Roberts (1998) where they attributed this anomaly to the high oxygen activity of the melt due to a case of volatiles saturation.

\section{PETROGENESIS}

The origin and evolution of igneous rocks can be estimated through the REE modeling calculations although the probable complications in the origin history due to the interference of more than one parent to produce the origin melt. Two common modeling are used to evaluate the igneous rocks petrogensis, the partial melting model (includes both batch melting and fractional melting) and the fractional crystallization.

The partition coefficients (Kds) of the different elements represent the main factor in the modeling calculations, these $\mathrm{Kds}$ are controlled by some physical conditions so their value for a given element may differ from basic, intermediate to acidic igneous melt, the used Kds in the present study are listed in Table (6).

Various sources are believed to be probable parent for the granitic melt such as, the dehydration melting of lower crust (Tepper et al., 1993, Rapp \& Watson, 1995 and Hassanen, 1999), the partial melting of either bulk continental crust or the upper continental crust (Abdel Wahed et al., 2007) and successive partial melting and fractional crystalliza- tion of intermediate magma (Mohammaden, 2000).

Several probable sources were examined to interpret the petrogenesis of the studied monzogranite, the bulk continental crust appeared the most suitable source with successive partial melting and fractional crystallization processes.

In the following models calculations, the average REE contents of the bulk continental crust (Taylor and McLennan, 1985) are used as a parent composition involved in generation of El-Yatima granitic melt.

The suggested modal mineralogy of the source is: $5 \%$ quartz, $5 \% \mathrm{~K}$-feldspar, $67 \%$ plagioclase, $15 \%$ hornblende, $4.5 \%$ biotite, $2 \%$ clinopyroxene and $1.5 \%$ ilmenite. At $70 \%$ partial melting of this source, the produced melt was considered the parent composition which affected by $30 \%$ fractional crystallization with assumed separated phases represented by $13.4 \%$ quartz, $66 \% \mathrm{~K}$-feldspars, $19 \%$ plagioclase, $1 \%$ hornblende, $0.3 \%$ biotite, $0.2 \%$ apatite and $0.1 \%$ allanite.

The data of the bulk continental crust, the $70 \%$ partial melting, the $30 \%$ fractional crystallization as well as the average of observed REE composition (El-Yatima monzogranite) are listed in Table (7). All these data are normalized against the REE chondritic values after Taylor and McLennan (1985) and diagrammatically represented on Fig. (19). The

Table 6: The partition coefficient (Kds) of the REE for rhyolitic and dacitic melts

\begin{tabular}{|c|c|c|c|c|c|c|c|c|c|c|c|c|}
\hline \multirow[b]{2}{*}{$\begin{array}{l}\text { Min. } \\
\text { Elem, }\end{array}$} & \multirow[b]{2}{*}{ Qz } & \multirow[b]{2}{*}{ K-feld. } & \multirow[b]{2}{*}{ Plag. } & \multirow[b]{2}{*}{$\mathbf{H b}$} & \multirow[b]{2}{*}{$\mathbf{B i}$} & \multirow[b]{2}{*}{ Cpx. } & \multicolumn{3}{|c|}{ Acidic Rocks } & \multicolumn{3}{|c|}{ Intermediate Rocks } \\
\hline & & & & & & & Ap. & Allanite & $\operatorname{Ilm}:$ & $\mathbf{H b}$ & Plag. & Cpx. \\
\hline La & 0.015 & 0.080 & 0.320 & 0.700 & 5.713 & 1.110 & 14.50 & 820.0 & 1.223 & 00.40 & 00.35 & 0.047 \\
\hline $\mathrm{Ce}$ & 0.014 & 0.044 & 0.270 & 0.899 & 0.037 & 0.500 & 34.70 & 635.0 & $01.64:$ & 00.51 & 00.24 & 0.084 \\
\hline Nd & 0.016 & 0.025 & 0.210 & 2.890 & 0.044 & 1.110 & 57.10 & 463.0 & 2.267 & 01.20 & 00.17 & 0.183 \\
\hline Sm & 0.014 & 0.018 & 0.130 & 6.990 & 0.058 & 1.670 & 62.80 & 205.0 & 2.833 & 02.00 & 00.13 & 0.377 \\
\hline Eu & 0.056 & 1.130 & 2.150 & 3.440 & 0.145 & 1.560 & 30.40 & 81.00 & 1.013 & 01.70 & 02.11 & 00.80 \\
\hline Gd & ---- & 0.011 & 0.900 & 5.480 & 0.082 & 1.850 & 56.30 & 130.0 & & 02.50 & 00.09 & 0.583 \\
\hline $\mathbf{Y b}$ & 0.017 & 0.012 & 0.077 & 4.890 & 0.179 & 1.580 & 23.90 & 8.900 & $1.467 \vdots$ & 02.00 & 00.77 & 0.633 \\
\hline $\mathbf{L u}$ & 0.014 & 0.006 & 0.062 & 4.530 & 0.185 & 1.540 & 20.20 & 7.700 & 1.203 & 01.60 & 00.62 & 0.665 \\
\hline
\end{tabular}


TAREK F. MOHAMMADEN et al.

Table 7: The estimated concentrations from partial melting model (70\%) followed by $30 \%$ fractional crystallization model to interpret the petrogenesis of El-Yatima monzogranite

\begin{tabular}{lrrrr}
\hline Element & $\begin{array}{r}\text { Source bulk } \\
\text { C.C }(\text { ppm) }\end{array}$ & $\begin{array}{r}\text { Partial } \\
\text { melting } \\
70 \%\end{array}$ & $\begin{array}{r}\text { Fractional } \\
\text { crystallization }\end{array}$ & $\begin{array}{r}\text { Observed composition } \\
\text { (El-Yatima } \\
\text { monzogranite) }\end{array}$ \\
\hline La & 16.0 & 18.36 & 18.58 & 19.49 \\
Ce & 33.0 & 42.25 & 54.40 & 52.35 \\
Nd & 16.0 & 20.00 & 30.10 & 28.91 \\
Sm & 3.50 & 04.21 & 08.26 & 08.12 \\
Eu & 1.10 & 00.89 & 00.55 & 00.44 \\
Gd & 3.30 & 03.95 & 07.48 & 09.32 \\
Yb & 2.20 & 02.75 & 07.83 & 08.87 \\
Lu & 0.30 & 00.38 & 01.11 & 01.34 \\
\hline
\end{tabular}

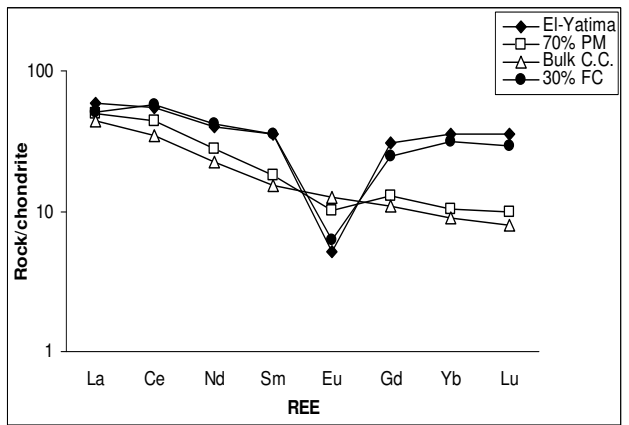

Fig. 19: Rock/chondrite normalized REE pattern of the estimated data from the different petrogenetic models for El-Yatima monzogranite

calculated data and the normalized REE pattern reflect the wide homogeneity between the REE composition after the successive $70 \%$ partial melting and $30 \%$ fractional crystallization and the REE composition of El-Yatima monzogranite.

\section{DISCUSSION AND CONCLUSIONS}

El-Yatima monzogranite occurs as isolated irregular small-dissected granitic masses covering an area of about $9 \mathrm{~km}^{2}$ forming moderate to low topographic features. It intrudes the low-lying older granites with sharp contacts. It is mainly medium- to coarse-grained granite of common equigranular, hypidiomorphic texture being porphyritic in places.
The petrographical study and the mineralogical modal analysis assigned El-Yatima granite as monzogranite and it is mainly composed of plagioclase, quartz, K-feldspars and biotite with accessory minerals represented by zircon, allanite and opaques. This is in agreement with the classification of El-Yatima granite reported by Moghazi et al. (1999) who recognized two varieties, the megacrystic biotite granite of medium to coarse-grained and fine to medium-grained one.

The geochemical studies defined El-Yatima monzogranite as A-type granite which originated from calc-alkaline magma of weak peraluminous nature and was emplaced in the within-plate environment. The $\mathrm{U}$ and Th contents of El-Yatima monzogranite recorded relative low values with averages of $7 \mathrm{ppm}$ and $19 \mathrm{ppm}$ respectively which differ than the assigned high radioactivity of El-Yatima granites as mentioned by Kamel and Abdel Hadi (1982). The uranium likely seems to be of magmatic origin with probable leaching from its bearing partial metamict zircon.

The rare earth elements and their normalized pattern revealed that El-Yatima monzogranite is characterized by relative enrichment of its LREE with relative depletion of the HREE which reflect the role of the accessory minerals in controlling the REE admission in the studied granite. Also, the present distinctive -ve Eu anomaly indicates the probable 
plagioclase depletion in the parent magma. Without REE data, Moghazi et al. (1999) suggested that El-Yatima A-type granite could be derived by fractional crystallization of mantle-derived mafic magma which could be formed by partial melting of the upper mantle. However, the REE modeling of the present study indicated that the plausible genesis of El-Yatima A-type granite comes from melt produced by $70 \%$ partial melting of the bulk continental crust and that melt was affected by $30 \%$ fractional crystallization then emplaced in an extensional-related tectonic environment.

\section{REFERENCES}

Abdel Rahman, A.M., and Martin, R. F., 1990. The Mount Gharib A-type granite, Nubian Shield: petrogensis and role of metasomatism at the source. Contrib. Mineral. Petrol. , 104, $173-183$

Abdel Wahed, A. A.; Moussa, E. M.; El-Husseiny, M. O.; El Sherif, A. M., and Ragab, A. I., 2007. Petrogenetic modeling of some granitic masses in the Central Eastern Desert, Egypt. Delta J. Sci., 31, 1-13.

Adams, J.A.S.; Osmond, J.K., and Rogers, J.J. W., 1959. The geochemistry of thorium and uranium, Physics and chemistry of the Earth, 3, Pergamon Press, London, 298-348.

Akaad, M.K., and Noweir, A.M., 1980. Geology and lithostratigraphy of the Arabian Desert orogenic belt of Egypt between Latitudes $25^{\circ}$ $35^{\prime}$ and $26^{\circ} 30^{\prime}$ N. Ins. Appl. Geol. Bull. King Abdulaziz Univ., 3, 127-135.

Arth, J.G., 1976. Behaviour of trace elements during magmatic processes-a summary of theoretical models and their applications. J. Res. United States Geol. Sur., 4, 41-47.

Assaf, H.S.; Mahdy, M.A., and El-Afandy, A.H., 1997. Egyptian younger granites, an approach to define parameters favouring formation of uranium deposits. $3^{\text {rd }}$ Conf. Geochem., Alexandria Univ., Egypt, 409-420.
Dardier, A.M.; Farag, S.S.; Abdel Ghani, I.M.; Arbab, A.A.; Abd El-Shafi, A.; Omran, A. A.;Ibrahim, S.E., and Zaher, F.Y. , 2002. Geological and radiometric prospection for Wadi Hawashiya-Gabal Um El-Tanasib area, North Eastern Desert, Egypt. Inter. report NMA Egypt .

Darnley, A.G., 1982. Hot granites, Some general remarks. In: Uranium in granites (Maurice, Y.J., Ed.). Geol. Surv. Canada, paper No. 8123, 1-10.

Eby, G.N., 1992. Chemical subdivision of the Atype granitoids: petrogensis and tectonic implications. Geology, 20, 641-644.

El-Gaby, S.; List, F.K., and Tehrani, R., 1988. Geology, evolution and metallo-genesis of the Pan-African belt in Egypt. In :The Pan-African belt of NE Africa and adjacent area. Vieweg, Braunschweig ( El-Gaby,S. \& Greiling ,R.O., Eds.), 17-68.

Fujimaki, H., 1986. Partition coefficients of Hf, $\mathrm{Zr}$ and REE between zircon, apatite and liquid. Contrib. Mineral. Petrol., 94, 42-45.

Greenberg, J.K., 1981. Characteristics and origin of Egyptian younger granites. Geol. Soc. Am. Bull., 91(II), 749-840.

Grenne, T., and Roberts, D., 1998. The Holanda porphyrite, Norwegian Caledonides: geochemistry and tectonic setting of early-Mid Ordovician shoshonitic volcanism. J. Geol. Soc., London, 155, 131-142.

Gunther, J.; Kleman, J., and Twist, D., 1989. The compositionally zoned sheet-like granite pluton of the Bushveld complex: Evidence bearing on nature of A-type magmatism. J. Petrol., $30,1383-1414$

Hanson, G.N., 1978. The application of trace elements to the petrogenesis of igneous rocks of granitic composition. Earth Planet. Sci. Letters, $38,26-43$.

Hanson, G.N., 1980. Rare earth elements in petrogenetic studies of igneous systems. Ann. Re- 
view Earth Planet. Sci., 8, 371-406.

Hassanen, A.M., 1999. Mantle-crustal source of mafic -felsic magmas in the Duber-Igla intrusive complex, Egypt: Inference from geochemistry and Sr-Nd isotopic study. Bull. Fac. Sci. Alex. Univ., 39(1,2), 17-52.

Hassanen, A.M.; El-Nisr, S.A., and Mohamed, F. H., 1996. Geochemistry and petrogenesis of Pan-African I-type granitoids at Gabal Igla Ahmar, Eastern Desert, Egypt. J. Afric. Earth Sci., 22 (1), 29-42.

Hume, W.F., 1935. Geology of Egypt, part II, The later plutonic and minor intrusive rocks. Geol. Surv. Egypt, 286p.

Hussein, A.A.; Ali, M.M., and El Ramly, M. F., 1982. A proposed new classification of the granites of Egypt. J. Volcan. Geother. Res., 14, 187-198.

Kamel, A.F., and Abdel Hadi, H.M., 1982. Photogeological and geophysical studies on the basement rocks in Wadi El Miyah, Eastern Desert of Egypt. J. Afric. Earth Sci., 15, 385-398.

Liew, T.; Finger, F., and Hock, V., 1989. The Moldanubian granitoid plutonic of Austria, chemical isotopic studies bearing their environmental setting. Chem. Geol., 76, 41-55.

Lumbers, S.B.; Wu, T.W.; Heaman, L.M.; Vertolli, V.M., and MacRae, N.D., 1991. Petrology and age of the A-type Mulock granite batholith, northern Grenville Province, Ontario. Precamb. Res., 53, 199-231.

Maniar, P.D., and Piccoli, P.M., 1989. Tectonic discrimination of granitoids. Geol. Soc. Am. Bull., 101, 635-643.

Middlemost, E.A.K., 1997. Magmas, Rocks and Planetary development. Longman Harlow, 299p.

Miller, C.F., and Mittlefehldt, D.W., 1982. Depletion of light rare earth elements in felsic magma. Geol., 10, 129-133.

Moghazy, A.M.; Mohamed, F.H.; El-Sayed, M. M., and Kanisawa, S., 1999. Geochemistry and petrogenesis of Late Proterozoic plutonic rock suites in the Homrit Waggat and El-Yatima area, Eastern Egypt. $4^{\text {th }}$ Intern. Conf. on Geochemistry, Alex. Univ., Egypt,1-12.

Mohamed, F.H.,1993. Rare metal-bearing and barren granites, Eastern Desert of Egypt: geochemical characterization and metallogenic aspects. J. Afr. Earth Sci., 19, 61-74.

Mohamed, F.H.; Hassanen, M.A.; Matheis, G. , and Shalaby, M.H.,1994. Geochemistry of the Wadi Hawashia granite complex, northern Egyptian Shield. J. Afr. Earth Sci., 19, 61-74.

Mohammaden, T.F., 2000. Petrographic, geochemical and isotopic characterization of granitoid rocks in Wadi Shawab area, South Wadi El Gemal, Eastern Desert, Egypt. Ph. D. Thesis, Fac. Sci., Ain Shams Univ., Cairo, 202p.

Nash, W.P., and Crecraft, H.R., 1985. Partition coefficients for trace elements in silicic magmas. Geochim Cosmo. Acta, 49, 2309-2322.

Pearce, J.A.,1996. Sources and setting of granitic rocks. Inter. New magazine, 9(4), 120-125.

Pearce, J. A.; Harris, N.B.W., and Tindle, A., 1984. Trace element discrimination diagrams for the tectonic interpretation of granitic rocks. Petrol., 25, 956-983.

Rapp, R.P., and Watson, E.B.,1995. Dehydration melting of metabasalt at 8-32 K-bar. Implications for continental growth and crust-mantle recycling. J. Petrol. , 36, 891-931.

Rogers, J.J., and Adams, J.A., 1969. Uranium and thorium. In: Handbook of geochemistry, (Wedepohl, K. H., Ed.)Springer Verlag, Berlin.

Rollinson, H.R., 1993. Using geochemical data: evaluation, presentation and interpretation. John Willey and Sons. Inc. New York.

Sabet, A.H.; Chabanenco, V., and Tsogoev, V., 1973. Tin-Tungsten and rare- metal mineralization in the Central Eastern Desert of Egypt. Ann. Geol. Surv. Egypt, III, 75-86. 
Sadek, A.A., 2006. Geology, geochemistry and radioactivity of Abu Fahm area with special emphasis on the granitic rocks, central Eastern Desert, Egypt. Ph. D. Thesis, Cairo Univ., $355 \mathrm{p}$.

Salem, M.A., 1983. Petrographical and geochemical studies of the granitic rocks of Um Samra and El Yatima plutons, Eastern Desert, Egypt. M.Sc. Thesis, El Azhar Univ., Cairo, Egypt, 83 p.

Shand, S.J.,1951. Eruptive rocks, John Wiley, New York, $488 \mathrm{p}$.

Shapiro, L., and Brannock, W.W., 1962. Rapid analysis of silicate, carbonate and phosphate rocks. U. S. Geol. Surv. Bull., 1144 (A), 56p.

Stern, R.J., 1979. Late Precambrian ensimatic volcanism in the Central Eastern Desert of Egypt. Ph. D. Thesis. California Univ., U.S.A., 210p.

Streckeisen, A.L., 1976a. Classification of the common igneous rocks by means of their chemical compositions. N. Jb. Min. J., 1-15.

Streckeisen, A.L.,1 976b. To each plutonic rock its proper name. Earth Sci. Rev., 12, 1-15.
Stuckless, J.S.; Nkomo, I.T.; Wenner, D.B., and Van Trump, G., 1984. Geochemistry and uranium favourability of the post-orogenic granites of the northwestern Arabian Shield, Kingdom of Saudi Arabia. In: Pan African crustal evolution in the Arabian -Nubian Shield (Convenor: A. M. Alshanti), Bull. Fac. Earth Sci. KAU (Jeddah), 6, 195-210, B. Bergamon Press. Oxford.

Taylor, S.R., and MacLennan, S.M., 1985. The continental crust; its composition and evolution. Blackwell, Oxford, 417p.

Tepper, J.H.; Nelson, B.K.; Bergantz, G.W., and Irving, A.J., 1993. Petrology of Chilliwack batholith, New York Cascadees, Washington: generation of calc-alkaline granitoids by melting of mafic lower crust with variable water fugacity. Contrib. Mineral. Petrol., 113, 333-351.

Whalen, J.B.; Currie, K.L., and Chappell, B.W., 1987. A-type granite: geochemical characteristics, discrimination and petrogenesis. Contrib. Mineral. Petrol., 95, 407-419.

White, A.J.R., and Chappell, B.W. , 1984. Granitoid types and their distribution in the Lachlan Fold Belt, Southeastern Australia. Geol. Soc. Mem., 159, 21-34.

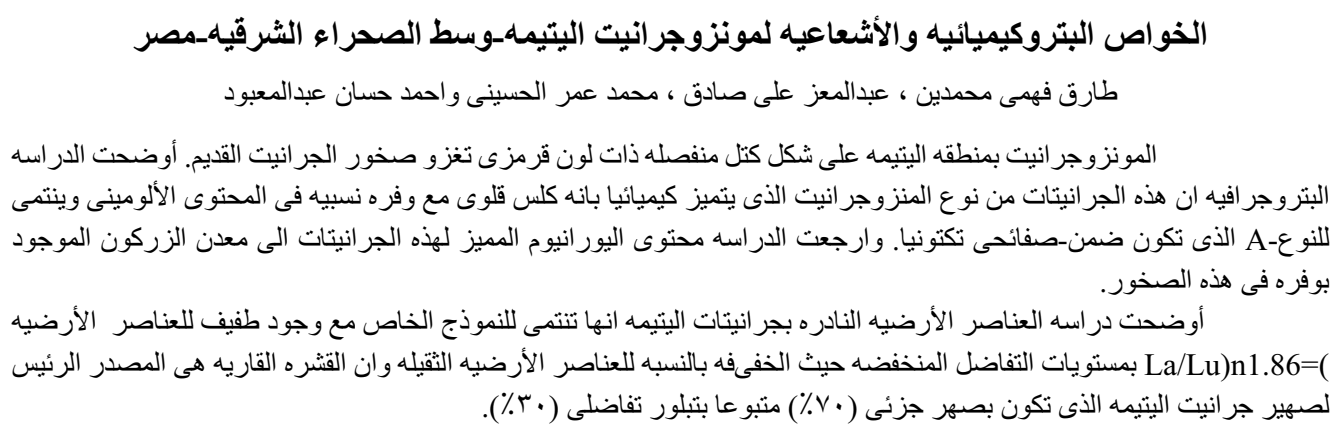

